\title{
Effects of Tourism Experience for Job Involvement and Well-Being
}

\author{
Cheng-Jong Lee ${ }^{1}$, Chieh-Heng Ko ${ }^{2}$, Yan-Chen Huang ${ }^{1}$, Yao-Hsu Tsai ${ }^{3{ }^{*}}$, Seng Keng ${ }^{4}$ \\ ${ }^{1}$ Department of Sport and Health Management, Da-Yeh University, Taiwan \\ ${ }^{2}$ Department of Hospitality Management, Da-Yeh University, Taiwan \\ ${ }^{3}$ Department of Tourism and Leisure, Chung Hua University, Taiwan \\ ${ }^{4}$ Department of Surgery, University of British Columbia, Canada
}

Received February 25, 2020; Revised March 17, 2020; Accepted March 28, 2020

Copyright $\bigcirc 2020$ by authors, all rights reserved. Authors agree that this article remains permanently open access under the terms of the Creative Commons Attribution License 4.0 International License

\begin{abstract}
This study uses the structural equation model as the analysis tool, and aims to explore the effects of tourism experience on job involvement and well-being. The subjects are full-time workers who have travelled in the last 12 months. This investigation is based on purposive sampling and e-questionnaires, uses analytical tools SPSS 18.0 and AMOS 19.0, and 360 valid questionnaires are retrieved. According to the research findings: (1) tourism experience positively influences job involvement; (2) tourism experience does not positively influence well-being; and (3) job involvement positively influences well-being. Based on the above, this study suggests that managers plan appropriate trips according to employees' demands. Experiential activities should be appealing and trigger internal affective connections through external experience, in order to reinforce job involvement and well-being in life. The research results also reveal that, of the five experiences, i.e., sensual experience, emotional experience, thinking experience, action experience, and related experience, the regression coefficient of emotional experience is the highest, which shows why story marketing has taken an important position among marketing strategies. The different types of tourism experience include recreational sightseeing, cultural sightseeing, entertaining sightseeing, and sports sightseeing where recreational sightseeing accounts for $58.1 \%$. Under the existing system, there may have been items that did not apply to the respondents, which would result in deviations or errors in the questionnaires; in the case of any special or major changes in the external environment
\end{abstract}

Keywords Tourism Experience, Job Involvement, Well-Being

\section{Introduction}

Holbrook and Hirschman (1982) pointed out that experience is a pleasing feeling, a psychological fantasy, an emotional expression, and aesthetical enjoyment, thus, tourism experience includes sentimental feelings, as well as rational consumption behaviors. After work, people experiencing tourism can be relieved from the pressures of life, both mentally and physically, thus, enhancing affection among families and friendship among friends, and when combined with recreational activities, tourism experience can further promote physical health. The sightseeing industry has influence on national economies; the influences of tourism experiences on personal mind and body are evidently important, and is one of the motives leading to this study.

To encourage employees, many enterprises take corporate tours as an employee reward mode, which intends to improve the degree of job involvement of employees to achieve performance goals. Thus, the second motive of this study is whether sightseeing tours, as provided by enterprises, or tourism experiences, will achieve personal pressure relief, reward, or growth, and can actually enhance job involvement.

People work most of their life, thus, the time for after-work recreational activities, including tourism experience, is long as well. It can be said that work and sightseeing cover most parts of well-being-related "integral assessment" in human life. Thus, this study proposes to discuss well-being from the perspectives of tourism experience and job involvement. 


\section{Background of the Research}

\subsection{Tourism Experience}

Experiences constitute an important concept in tourism studies and the tourism industry (Uriely, 2005) since the 1970s (e.g. MacCannell, 1973; Csikszentmihalyi, 1975; Cohen, 1979), as tourism is determined by a high level of interactions between service people and tourists (e.g. Larsen, 2007) and such interactions lead to the formation of individual tourist experiences (Mossberg, 2003), which are obtained at the moment of value creation when tourism production and consumption meet (Andersson, 2007).

Tourism organizations often attempt to provide consumers with something extraordinary (Morgan \& Watson, 2009). In the wake of the experience economy (Pine \& Gilmore, 1999) and consumer research (Arnould \& Price, 1993), research has focused on extraordinary products, which are experienced as something extra or surprising (Mossberg, 2007). The focus is the co-creative role of consumers in the production of memorable experiences (Prahalad \& Ramaswamy, 2004). In organizing extraordinary experiences, businesses mobilize operand resources (e.g., tangible aspects of experiences capes) and operant resources (e.g., intangible aspects, such as themes and stories) to offer value propositions to consumers (Vargo \& Lusch, 2004). The experience is completed when consumers bring their own resources and co-create a staged act (Deighton, 1992), meaning the consumer receives "more intense, framed, and stylish practices", which stand out as special and memorable moments (Abrahams, 1986).

A tourist experience can be conceptualized in terms of its relation to the strangeness of the "other" (e.g., foreign culture), as well as to the tourist's zone of novelty (Cohen, 1972). Cohen later claimed that the view of tourists' experiences depends on "the place and significance of tourist experience in the total world-view of tourists" (Cohen, 1979).

Tourism experiences are formed through ongoing interpretations within the world bound to the concrete situation of the consumer (Pernecky \& Jamal, 2010). Normally, the experience of everyday human life and the transformations between activities are familiar, and a tacit aspect of being-in-the-world. How people understand, interpret, and create meaning would consequently often be familiar and tacit (Alvesson \& Sköldberg, 2009). In situations in which the familiar becomes unfamiliar, and perhaps challenging (which can occur within extraordinary tourism contexts; Tumbat \& Belk, 2011), one’s belonging in the world tends to become thematized, and takes the form of reflection on action. Furthermore, meetings in tourism contexts will enable tourists to learn about the worlds, themselves, and other people, as such contexts often "force" a different horizon of understanding on tourists through their transformative experiences and the tourism moment (Cary, 2004).

\subsection{Job Involvement}

Job involvement is considered a key factor that could lead to personal growth, satisfaction, and goal-directed behavior within the workplace, thus, from an organizational perspective, job involvement has been considered essential in ensuring employee motivation, which, in turn, is a fundamental factor in facilitating competitive advantage (Latha, 2012).

Robinson et al., (2004) said job involvement is a popular term and an important construct, and is of great use in employee performance. The results of several researches show the relationship among work outcomes and job involvement. Some scholars have presented positive associations between organizational commitment and job involvement, while some have indicated negative connections with turnover intention, which has direct impact on employee performance (Sonnentag, 2003; Schaufeli \& Bakker, 2004). Van der Westhuizen (2006) discussed job involvement in terms of the dispositional perspective, the situational perspective, and the interaction between these two approaches. From the situational perspective, certain situational variables have been shown to be related to job involvement. The situational perspective suggests that job involvement can be influenced by experiences and psychological reactions to a person's work (Carmeli, 2005). The interactive perspective of job involvement explains job involvement as a function of the interaction between personal characteristics and the situation (or the working environment). As Kanungo (1982) suggested, the interaction between individual differences and situational factors influences job involvement. Thus, personality and situational factors jointly influence a person's level of job involvement. Ultimately if personality characteristics and situational factors are in congruence, an employee will develop higher levels of job involvement (see Ho, 2006). Van der Walt and Swanepoel (2015) suggested that a change in job involvement can be attributed to workplace spirituality.

\subsection{Well-Being}

According to Diener (1984), well-being reflects how people feel and what they think about their lives, and therefore, includes emotional and cognitive assessment of one's life. Emotional assessment is based on feelings mood and emotions, while cognitive assessment is known as life satisfaction (Diener, 1984; Diener \& Chan, 2011). Thus, the construct of well-being consists of a few components: life satisfaction, positive affect or frequent experience of positive emotions (feeling of happiness), and low levels of negative affect or the relative absence of unpleasant emotions (such as dejection) (Diener, 1984; Luhmann et al., 2012). 
Well-being is a critical indicator of psychological functioning and positive human health (Mihalko \& McAuley, 1996). One feature of well-being is subjective well-being, which includes three relatively independent components: positive affect, negative affect, and life satisfaction (Emmons \& Diener, 1985). Positive affect can be regarded as the degree to which a person experiences joy and happiness in life (Emmons \& Diener, 1985). Negative affect refers to unpleasant emotions, which are independent from the positive affect. Life satisfaction is defined as "a global assessment of a person's quality of life according to their chosen criteria'” (Shin \& Johnson, 1978,).

In recent years, workplace well-being has increasingly attracted researchers and practitioners (Meyer and Maltin, 2010). Previous studies focused on ill-health consequences, while less attention has been given to positive employee well-being (Schaufeli, 2004; Wright and Cropanzano, 2000). The investigation of employee well-being is significant for employee's "optimal functioning", as well as improving health, happiness, and betterment in life (Schaufeli, 2004). Well-being is a subjective concept experienced through pleasant emotions, meaning self-evaluated happiness, by engaging in interesting and fulfilling activities, and refers to a generalized feeling of satisfaction with life (Cartwright and Cooper, 2014). Interestingly, a relatively low correlation between well-being and personal income is found, which indicates that material wealth itself does not create happiness (Myers, 2000). Elders' relational well-being and positivity significantly contribute to life satisfaction (Francescato, 2017).

Employee well-being is also a core interest of organizations to gain benefit in terms of generating products and profits. A recent survey clearly showed that most employees see or desire meaningful, enjoyable, and socially useful work in their organizations (Avolio and Sosik, 1999; Wrzesniewski, McCauley, Rozin, and Schwartz, 1997).

\section{Methodologies}

\subsection{Hypotheses}

According to the recovery theory, the removal of work demands will facilitate recovery from work (Meijman \& Mulder, 1998). Recovered employees that can gain job resources in the recovery process are willing to exert effort on work tasks and dedicate themselves to work (Sonnentag, 2003).

Tourism has been recognized as a great opportunity to recover from work demands (De Bloom et al., 2010), as it provides employees with a sense of escapism and release from work tension (Rubinstein, 1980). Obtaining experience in tourism can contribute to employees' recovery and acquisition of resources that foster work engagement (Schaufeli \& Bakker, 2004; Sonnentag, 2003). Therefore, it is plausible to assume that highly tourism-experienced employees have high tendency to engage in their work. Accordingly, the first hypothesis is developed, as follows.

H1: Tourism experience has positive influence on job involvement

Tourism has been seen to exert positive psychological impact on people, on their subjective wellbeing, quality of life, self-assessed health, and life satisfaction, regardless of the type or duration of the tourism activity (Dolnicar, Yanamandram, \& Cliff, 2012; Hagger \& Murray, 2013; Hunter-Jones \& Blackburn, 2007). Similarly, tourism plays a role in creating and sharing memories (Marschall, 2012; Sellick, 2004; Tung \& Brent Ritchie, 2011) and reminiscence, and is recognized as promoting and maintaining people's mental wellbeing, as it engages memory and fosters social interaction (Coleman, 2005; Mullins, 2011). Based on the above-mentioned literature and deductions, the following hypotheses are put forward in this research:

H2: Tourism experience has positive influence on well-being

Previous research shows that job involvement increases positive attitudinal and behavioral outcomes, including job satisfaction and performance (e.g. Macky and Boxall, 2007; Alfes et al., 2012; Piening et al., 2013); although there are variations within (e.g. Kinnie et al., 2005; Kooij et al., 2010) and across (e.g. Piening et al., 2014) the contexts. Moreover, job involvement is associated with higher levels of well-being (Alfes et al., 2012) and lower levels of stress and emotional exhaustion (Kalmi and Kauhanen, 2008). Based on the above-mentioned literature and deductions, the following hypotheses are put forward in this research:

H3: Job involvement has positive influence on well-being

\subsection{Tools}

This study adopts the quantitative questionnaire method, meaning the questionnaire is compiled based on the research purpose and framework, as well as by literature review and referencing scales developed by relevant scholars. Its content covers the revised and compiled contents of three main research variables, i.e., tourism experience, job involvement, and well-being, as well as personal background information. The scale is scored according to a five-point Likert-type aggregation scale method, which is detailed, as follows:

\section{1) Sightseeing experience scale}

This study applies five aspects brought forward by Schmitt (1999), i.e., T1: "sensual experience", T2: "emotional experience", T3: "thinking experience", T4 "action experience", and T5 "related experience", which consist of 15 question items; because the subjects had to 
possess experience in tourism, this study considers their degree of experience, and limits inclusion to sightseeing activities within the past one year.

\section{2) Job involvement scale}

According to two aspects of a scale proposed by Kanungo (1982) and Brown et al. (1996), i.e., J1: “degree of job involvement” and J2:"importance of work identity”, which consist of ten question items in total, the research subjects are those committed to full-time jobs of high pressure or general nature, as they must have experience in job involvement.

\section{3) Well-being scale}

The five question items in the well-being scale proposed by Chiu and Tung (2010) include: W1) I think life is very significant and targeted; W2) my past life; everything was pleasing; W3) I feel very happy; W4) I am highly satisfied with my current life; W5) I am optimistic about my future.

\section{4) Personal background information}

The personal basic data in this questionnaire are mainly compiled to gather the background data of the subjects, in order that they could be taken as reference for follow-up research and analysis. The personal basic data consist of five question items, i.e., "type of sightseeing experience", “job nature”, “gender”, “age group”, and “educational background”.

\subsection{Procedures}

The sampling mode for the questionnaire of this study is purpose sampling, 72 effective electronic questionnaires are recovered in the pre-examination, and the reliability of the tourism experiences and job involvement scales are scored, as follows: if 80 is scored, it indicates that an extremely high reliability level is reached; if more than 76 is reached, it indicates that a high reliability level is reached, and internal consistency is good. There are 350 formal electronic questionnaires recovered, and the reliability of all variables is more than .8 (see Table 1 ).

The statistical methods adopted include descriptive analysis, reliability, and Structural Equation Modelling (SEM); statistical analysis is carried out with SPSS 18.0 and AMOS 19.0 statistical software.

\section{Result}

\subsection{Description of the Sample Structure}

According to the statistics on the questionnaire results, most types of tourism experiences are "recreational sightseeing”, with 209 people accounting for $58.1 \%$ of the samples, followed by “cultural sightseeing”, with 71 people accounting for $19.7 \%$ of the samples; 52 people are in the category of "sports sightseeing", accounting for $14.4 \%$ of the samples; the number of "recreational sightseeing" samples is the smallest, with 28 people accounting for $7.8 \%$ of the samples.

Regarding the distribution of job nature, "other personnel” account for the largest proportion, with 198 and accounting for $55 \%$ of the samples; there are a total of 162 "police, firefighters, and nurses", accounting for $45 \%$ of the samples.

Regarding gender, "Female" is the most, with 185 accounting for 51.4\%; and "Male" with 175 people accounting for $48.6 \%$ of the samples.

Regarding age group, people aged "below 29 years old" are the least, with 54 people accounting for $15 \%$ of the total number of samples; people aged "30 to 39 years old" are the most, with 131 people accounting for $36.4 \%$ of the samples, followed by people aged " 40 to 49 years old”, with 115 people accounting for $31.9 \%$ of the samples; and 60 people aged "above 50 years old”, accounting for $16.7 \%$ of the samples.

Regarding educational level, "Bachelor Degree" is the most, with 204 people accounting for $56.7 \%$ of the samples, and followed by "Junior college" degree, with 106 people accounting for $29.4 \%$ of the samples; there are 48 people with "Masters", accounting for $13.3 \%$ of the samples; the number of "Doctors" was the smallest, with only 2 people, accounting for $0.6 \%$ of the total number of samples.

\subsection{Reliability Analysis}

This study conducts reliability analysis on a three-variable scale consisting of "tourism experience", "job involvement”, and "well-being”, which is designed by the SPSS 12.0 software package, and results in all variable scales with Cronbach $\alpha$ values of more than .80 . This indicates that the questionnaire has the optimal reliability level. The sorted analysis on the reliability of all variable scales is shown in Table 1:

Table 1. Analysis of the Reliability of All Variable Scales of the Formal Questionnaire

\begin{tabular}{|c|c|c|c|}
\hline Variable scales of the research & Number of titles & Cronbach's $\alpha$ value & Assessment result \\
\hline Tourism experience & 15 & .912 & High reliability \\
\hline Job involvement & 10 & .845 & High reliability \\
\hline Well-Being & 5 & .826 & High reliability \\
\hline
\end{tabular}




\subsection{Confirmatory Factor Analysis}

After confirmatory factor analysis, the goodness of fit indices is generated as GFI $=.960$, AGFI $=.929$, $\mathrm{NFI}=.953$, $\mathrm{TLI}=.962$, CFI $=.975$, RMSEA $=.055$, and $\mathrm{RMR}=.016$, which are in accordance with standard indices, and some analysis results indicate that the sightseeing scale mode has good goodness of fit. Confirmatory factor analysis of the sightseeing scale shows that the loading of the standard factors of all question items range from .667 to .891, which is significantly larger than .5. This indicated that the mode has good basic goodness of fit and all question items have good convergent validity in the potential variables. The combined reliability of the five potential variables in the scale is more than .6, signaling that the internal model is ideal; the average variables extracted are mostly more than .5.

Confirmatory factor analysis of the job involvement scale shows that all goodness of fit indices is generated as: $\mathrm{GFI}=.964$, AGFI $=.931$, NFI $=.926$, TLI $=.926$, CFI $=.950$, RMSEA $=.072$, and $\mathrm{RMR}=.030$, which are all in accordance with the standard indices, and some analysis results indicate that the job involvement scale mode has good goodness of fit.

Confirmatory factor analysis of the job involvement scale shows that the loading of the standard factors of all question items is from .513 to .668, which is larger than .5. This indicated that the mode has good basic goodness of fit and all question items have good convergent validity in the observational variables. The combined reliability of the two observational variables in the scale is more than .6, signaling that the internal model is ideal; the average variables extracted are .325 and .389 , respectively, which does not meet the standard value of .5 .

Discriminatory validity refers to the question items among different aspects, which should be lowly related to one another. Hatcher (1994) pointed out that, if the confidence interval formed by the shared variable and the standard error of the scale (shared variable $\pm 2 \times$ standard error) does not contain 1, it indicates that the scale has discriminatory validity. Pairwise comparison analysis shows that the confidence intervals of the research questionnaire do not contain 1 , signaling that the scale has good discriminatory validity.

\subsection{Study Model Assessment}

This study assesses integral goodness of fit according to the research theme and structure, as well as nine judgment indicators of Hair, Anderson, Tatham, and Black (1998). The analysis results are, as follows: GFI=.928, AGFI $=.890$, NFI $=.903, \quad$ TLI $=.910, \quad$ CFI $=.931, \quad$ RMSEA $=.079$, $\mathrm{RMR}=.027$, which all meet the standard value, and indicate that the integral mode basically accords with the ideal standard, has good explanatory power, and requires no revision. See Figure 1 for details.

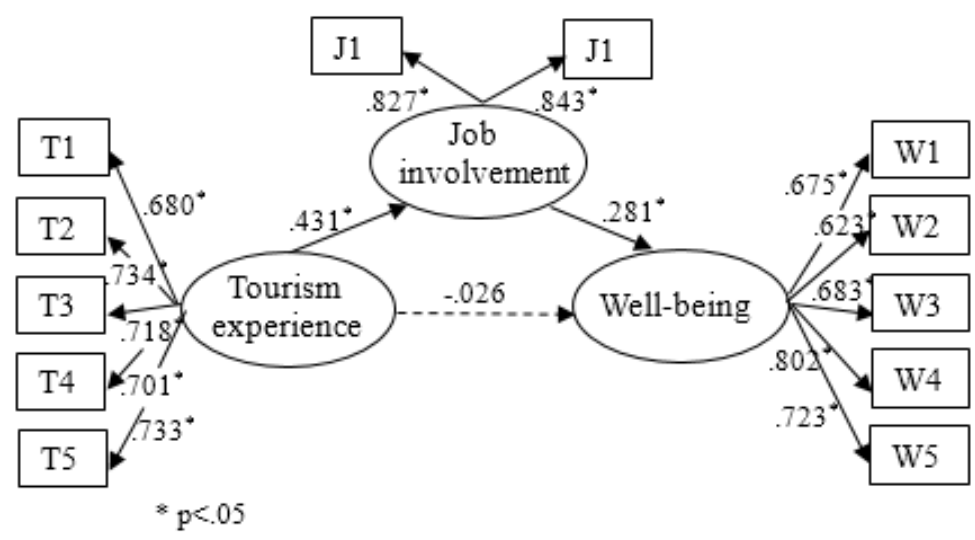

Figure 1. Results of hypotheses testing. 


\subsection{Hypothesis Testing}

This study uses AMOS statistical software to empirically analyze the various hypotheses, in order to learn the influence of tourism experience on job involvement and well-being. The empirical result is, as follows:

H1: Tourism experience has positive influence on job involvement

Judging from the analytical result of Figure 1, the regression coefficient of tourism experience to job involvement is .431 and $\mathrm{p}<.05$, which reaches the significant level, and Hypothesis 1 is supported. This result indicates that tourism experience has positive influence on job involvement.

$\mathrm{H2}$ : Tourism experience has positive influence on well-being.

Judging from the analytical result of Figure 1, the regression coefficient of tourism experience to well-being does not reach the significant level, thus, $\mathrm{H} 2$ is false.

H3: Job involvement has positive influence on well-being.

Judging from the analytical result of Figure 1, the regression coefficient of job involvement to well-being is .281 and $p<.05$, which reaches the significant level, thus, Hypothesis 2 is supported. This result indicates that tourism experience has positive influence on well-being.

\section{Conclusions}

1. Influence of tourism experience on job involvement

Judging from Figure 1, the effect of "importance of job involvement" is reflected most obviously during the measurement of job involvement by the subjects. It can be seen that, for personal tourism experiences, the influence of "importance of job involvement" is highest; according to the research result, frequently participating in tourism experience can contribute to the improvement of job involvement.

\section{Influence of job involvement on well-being}

According to the research result, the effect of "feeling satisfied" is most obvious in the measurement of well-being by the subjects. It can be seen that, the influence of job involvement on "feeling satisfied towards life or not" is the highest. Thus, making employees focus on job involvement will make job involvement become an important part of life to facilitate personal satisfaction, which will further generate well-being.

3. Job involvement has medium effect on the way tourism experience influences well-being.

Judging from the data in Figure 1: Tourism experience has no positive influence on well-being, the influence of tourism experience on job involvement reaches the significant level (.431, $\mathrm{p}<.05)$; and job involvement also has positive influence on well-being (.281, $\mathrm{p}<.05)$. This indicates that tourism experience can indirectly influence well-being through job involvement. Moreover, while the direct effect of tourism experience to well-being is not significant ( $>.05)$, the indirect effect value is equal to $.431 \times .281=.121>.026$, meaning when well-being is reached (regression coefficient: .281) through job involvement (regression coefficient: .431). This indicates that job involvement has medium effect on the way tourism experience influences well-being.

\section{Implications}

\section{Contributions to academic research}

While there is plentiful literature regarding the research of "job involvement" and "well-being", literature concerning "tourism experience" are few, thus, this study focuses on tourism experience, job involvement, and well-being, and puts forward a relevant integrated framework to clarify the influences among the above-said variables.

\section{Deduced practical connotation of tourism experience}

Based on the research conclusions, proper practical suggestions should be provided for managerial connotation, which can be used as reference by the public and private departments of relevant organizations.

\section{1) Focusing on the core demand}

According to the research results, the different types of tourism experience include recreational sightseeing, cultural sightseeing, entertaining sightseeing, sports sightseeing, etc.; where recreational sightseeing accounts for $58.1 \%$. Thus, public departments can emphasize recreational sightseeing when promoting the sightseeing tourism industry, which meets public demand and is advantageous for the development of the sightseeing industry; incentive measures developed by companies for corporate welfare can be planned as recreational sightseeing, according to employees' expectations, and contribute to job involvement and increased performance.

\section{2) Emphasizing emotional dependence}

Regarding practitioners, tourists' emotional connections can be triggered through the experiences of story marketing, which help create emotions and memories. Furthermore, tourists will be willing to return for repeated tours, thus, creating a sightseeing business. Regarding agencies or enterprises, through advance planning, touring processes are repeated, employee demands are considered and respected from many perspectives and in detail, and added surprises during activities will cause emotional connections between the individuals and the agencies, 
which shows the importance of job involvement, and contributes to job involvement improvement.

3) Good incentive mechanism

Enterprises generally plan their incentive mechanisms based on their organizational strategies, and urge their employees to achieve their performance goals. Sightseeing is a common incentive mode. After a performance goal is formulated, the integral economic environment, as well as other influencing factors, such as industrial low and high seasons, industrial cycling period, etc., can be considered and adjusted at the right time, in order that the employees can achieve their performance goals through their own efforts. The employees can enhance their satisfaction with life through self-actualization (achieving the performance and acquiring the reward of a sightseeing opportunity), as psychological well-being is originated from humanism.

\section{Limitations and Further Research}

Under the existing system, there may have been items that did not apply to the respondents, which would result in deviations or errors in the questionnaires; in the case of any special or major changes in the external environment (e.g., earthquake and other natural disasters, financial and political events, etc.), the question items and options were already preset before the questionnaire survey of this quantitative research. Thus, future research should adopt qualitative research, in order that problems can be fully learned through negotiations, and in-depth research data can be obtained for research analysis and discussion.

\section{REFERENCES}

[1] Abrahams, R. D. (1986). Ordinary and extraordinary experience. In V. W. Turner \& E. M. Bruner (Eds.). The Anthropology of Experience (pp. 45-73). Urbana, IL: University of Illinois Press.

[2] Andersson T. D. (2007). The tourist in the experience economy. Scandinavian Journal of Hospitality and Tourism, 7(1), 46-58.

[3] Alfes, K., Shantz, A. \& Truss, C. (2012). The link between perceived HRM practices, performance and well-being: the moderating effect of trust in the employer. Human Resource Management Journal, 22(4), 409-427.

[4] Alvesson, M., \& Sköldberg, K. (2009). Reflexive methodology. New vistas for qualitative research (2nd ed.). London, England: Sage.

[5] Arnould, E. J., \& Price, L. L. (1993). River magic: Extraordinary experiences and the extended service encounter. Journal of Consumer Research, 20(1), 24-45.

[6] Avolio, B., \& Sosik, J. (1999). A life-span framework for assessing the impact of work on white-collar workers. Life in the middle: Psychological and social development in middle age, 251-274.

[7] Brown, S. P. (1996). A meta-analysis and review organizational research on job involvement. Psychological Bulletin, 120(2), 235-255.

[8] Carmeli, A. (2005). Exploring determinants of job involvement: An empirical test among senior executives. International Journal of Manpower, 26(5), 457-472.

[9] Cary, S. H. (2004). The tourist moment. Annals of Tourism Research, 31(1), 61-77.

[10] Cartwright, S., \& Cooper, C. L. (2014). Towards organizational health: Stress, positive organizational behavior, and employee well-being, Bridging Occupational, Organizational and Public Health, 29-42, Springer.

[11] Chiu, H. C., \& Tung, H. I. (2010). A Study on the contents of teachers' well-being. School Administration, 67, 168 - 180.

[12] Cohen, E. (1972). Towards a sociology of international tourism. Social Research, 39(1), 164-182.

[13] Cohen, E. (1979). A phenomenology of tourist experiences. Sociology, 13(2), 179-201.

[14] Coleman, P. G. (2005). Uses of reminiscence: Functions and benefits. Ageing and Mental Health, 9(4), 291-294.

[15] Csikszentmihalyi, M. (1975). Beyond boredom and anxiety: The experience of play in work and games. Jossey-Bass Publishers: San Francisco.

[16] De Bloom, J., Geurts, S. A. E., Taris, T. W., Sonnentag, S., De Weerth, C., \& Kompier, M. A. J. (2010). Effects of vacation from work on health and well-being: Lots of fun, quickly gone. Work and Stress, 24(2), 196-216.

[17] Deighton, J. (1992). The consumption of performance. Journal of Consumer Research, 19(3), 362-372.

[18] Diener, E. (1984). Subjective well-being. Psychological Bulletin, 85, 542-575.

[19] Diener, E., \& Chan, M. Y. (2011). Happy people live longer: Subjective well-being contributes to health and longevity. Applied Psychology: Health and Well-Being, 3(1), 1-43.

[20] Dolnicar, S., Yanamandram, V., \& Cliff, K. (2012). The contribution of vacations to quality of life. Annals of Tourism Research, 39(1), 59-83.

[21] Emmons, R. A., \& Diener, E. (1985). Factors predicting satisfaction judgments: A com-parative examination. Social Indicators Research, 16, 157-167.

[22] Francescato, D., Pezzuti, L., Mebane, M., Tomai, M., \& Benedetti, M. (2017). Dispositional characteristics, relational well-being and perceived life satisfaction and empowerment of elders. Aging \& Mental Health, 21(10), 1052-1057.

[23] Hagger, C., \& Murray, D. (2013). Anticipating a flourishing future with tourism experiences. In S. Filep \& P. Pearce (Eds.), Tourist experiences and fulfilment: Insights from positive psychology (pp. 186-202). Abingdon: Routledge.

[24] Hair, J. F. J., Anderson, R. E., Tatham, R. L., \& Black, W. C. (1998). Multivariate data analysis. New Jersey: 
Prentice-Hall.

[25] Holbrook, M. B., \& Hirschman, E. C. (1982). The experiential aspects of consumption: Consumer fantasies, feelings, and fun. Journal of Consumer Research, 9(2), 132-140.

[26] Ho, C. C. (2006). A study of the relationships between work values, job involvement and organizational commitment among Taiwanese Nurses. Doctoral Dissertation. Australia: Queenslan University of Technology.

[27] Hunter-Jones, P., \& Blackburn, A. (2007). Understanding the relationship between holiday-taking and self-assessed health: An exploratory study of senior tourism. International Journal of Consumer Studies, 31, 509-516.

[28] Kanungo, R. N. (1982). Measurement of job and work involvement. Journal of Applied Psychology, 67(3), 341-349.

[29] Kalmi, P. \& Kauhanen, A. (2008). Workplace innovations and employee outcomes: evidence from Finland. Industrial Relations: A Journal of Economy and Society, 47(3), 430 459.

[30] Kinnie, N., Hutchinson, S., Purcell, J., Rayton, B. and Swart, J. (2005). Satisfaction with HR practices and commitment to the organization: why one size does not fit all. Human Resource Management Journal, 15(4), 9-29.

[31] Kooij, D., Jansen, P., Dikkers, J. \& De Lange, A. (2010). The influence of age on the associations between HR practices and both affective commitment and job satisfaction: a meta-analysis. Journal of Organizational Behavior, 31(8), 1111-1136.

[32] Larsen, S. (2007). Aspects of a psychology of the tourist experience. Journal of Hospitality and Tourism, 7(1), 7-18.

[33] Latha, R. (2012). A study on job involvement and organizational performance of workers in NLC Limited, Tamil Nadu. Journal of Radix International Educational and Research Consortium, 1(9), 1-12.

[34] Luhmann, M., Hofmann, W., Eid, M., \& Lucas, R. E. (2012). Subjective well-being and adaptation to life events: a meta-analysis. Journal of personality and social psychology, 102(3), 592.

[35] MacCannell, D. (1973). Staged authenticity: Arrangements of social space in tourist settings. The American Journal of Sociology, 79(3), 589-603.

[36] Macky, K. \& Boxall, P. (2007). 'The relationship between "high-performance work practices" and employee attitudes: an investigation of additive and interaction effects'. The International Journal of Human Resource Management, 18(4), 537-567.

[37] Marschall, S. (2012). Personal memory tourism' and a wider exploration of the tourism-memory nexus. Journal of Tourism and Cultural Change, 10(4), 321-335.

[38] Meijman, T. F., \& Mulder, G. (1998). Psychological aspects of workload. In H. T. Drenth \& C. J. D. Wolff (Eds.). Handbook of work and organizational psychology (Vol. 2, pp. 5-33). Hove, England: Psychology Press.

[39] Meyer, J. P., \& Maltin, E. R. (2010). Employee commitment and well-being: A critical review, theoretical framework and research agenda. Journal of Vocational Behavior, 77(2), 323-337.

[40] Mihalko, S. L., \& McAuley, E. (1996). Strength training effects on subjective well-being and physical function in the elderly. Journal of Aging and Physical Activity, 4, 56-68.

[41] Morgan, M., \& Watson, P. (2009). Unlocking the shared experience. In M. Kozak \& A. DeCrop (Eds.), Handbook of tourist behavior (p. 116-130). New York, NY: Routledge.

[42] Mossberg L. (2003). Att skapa upplevelser: från OK till WOW. Studentliteratur: Lund.

[43] Mossberg, L. (2007). Å skape opplevelser. Fra OK til WOW! [To create experiences. From OK to WOW!]. Bergen, Norway: Fagbok forlaget.

[44] Mullins, J. (2011). Exploring the role and benefits of leisure and short breaks for people with mild dementia and their partners. Paper presented at the Fourth Critical Tourism Studies Conference, Cardiff July.

[45] Myers, D. G. (2000). The funds, friends, and faith of happy people. American psychologist, 55(1), 56.

[46] Pernecky, T., \& Jamal, T. (2010). Phenomenology in tourism studies. Annals of Tourism Research, 37(4), 10551075.

[47] Prahalad, C. K., \& Ramaswamy, V. (2004). Co-creation experiences: The next practice in value creation. Journal of Interactive Marketing, 18(3), 5-14.

[48] Piening, E., Baluch, A. \& Ridder, H. (2014). Mind the intended-implemented gap: understanding employees' perceptions of HRM. Human Resource Management, 53(4), 545-567.

[49] Pine, B. J., \& Gilmore, J. H. (1999). The experience economy: Work is theatre \& every business a stage. Boston, MA: Harvard Business School Press.

[50] Rubinstein, C. (1980). Vacations expectations, satisfactions, frustrations, fantasies. Psychology Today, 14, 62-66.

[51] Robinson, D., Perryman, S., \& Hayday, S. (2004). The Drivers of Employee Engagement. Brighton. Institute for Employment Studies.

[52] Schaufeli, W. B. (2004). The future of occupational health psychology. Applied Psychology, 53(4), 502-517.

[53] Schaufeli, W. B., \& Bakker, A. B. (2004). Job demands, job resources, and their relationship with burnout and engagement: A multisampling study. Journal of Organization Behavior, 25, 293-315.

[54] Sellick, M. C. (2004). Discovery, connection, nostalgia: Key travel motives within the senior market. Journal of Travel and Tourism Marketing, 17(1), 55-71.

[55] Shin, D. C., \& Johnson, D. M. (1978). Avowed happiness as an overall assessment of the quality of life. Social Indicators Research, 5, 475-492.

[56] Sonnentag, S. (2003). Recovery, work engagement, and proactive behavior: A new look at the interface between non-work and work. Journal of Applied Psychology, 88(3), 518-528. 
[57] Schmitt, B. H. (1999). Experiential marketing: How to get customers to sense, feel, think, act and relate to your company and brand. New York: The Free Press.

[58] Tumbat, G., \& Belk, R. W. (2011). Marketplace tensions in extraordinary experiences. Journal of Consumer Research, 38(1), 42-61.

[59] Tung, V., \& Brent Ritchie, J. R. (2011). Investigating the memorable experiences of the senior travel market: An examination of the reminiscence bump. Journal of Travel and Tourism Marketing, 29, 331-343.

[60] Uriely, N. (2005). The tourist experience: conceptual developments. Annals of Tourism Research, 32(1), 199216.

[61] Vargo, S. L., \& Lusch, R. F. (2004). Evolving to a new dominant logic for marketing. Journal of Marketing, 68(1), $1-17$.

[62] Van der Walt, F., \& Swanepoel, H. (2015). The relationship between workplace spirituality and job involvement: A South African study. African Journal of Business and Economic Research, 10(1), 95-116.

[63] Van der Westhuizen, C. (2006). Work related attitudes as predictors of employee absenteeism. Master Dissertation. Pretoria: University of South Africa.

[64] Wright, T. A., \& Cropanzano, R. (2000). The role of organizational behavior in occupational health psychology: A view as we approach the millennium. Journal of occupational health psychology, 5(1), 5.

[65] Wrzesniewski, A., McCauley, C., Rozin, P., \& Schwartz, B. (1997). Jobs, careers, and callings: People's relations to their work. Journal of research in personality, 31(1), 21-33. 